\title{
Oxaliplatin-induced blood brain barrier loosening: a new point of view on chemotherapy-induced neurotoxicity
}

\author{
Jacopo Junio Valerio Branca ${ }^{1}$, Mario Maresca ${ }^{2}$, Gabriele Morucci ${ }^{1}$, Matteo Becatti ${ }^{3}$, \\ Ferdinando Paternostro ${ }^{1}$, Massimo Gulisano ${ }^{1}$, Carla Ghelardini ${ }^{2}$, Daniela Salvemini ${ }^{4}$, \\ Lorenzo Di Cesare Mannelli ${ }^{2, *}$ and Alessandra Pacini ${ }^{1, *}$ \\ ${ }^{1}$ Department of Experimental and Clinical Medicine, Anatomy and Histology Section, University of Florence, Florence, Italy \\ ${ }^{2}$ Department of Neuroscience, Psychology, Drug Research and Child Health (NEUROFARBA), Pharmacology and Toxicology \\ Section, University of Florence, Florence, Italy \\ ${ }^{3}$ Department of Experimental and Clinical Biomedical Sciences "Mario Serio", University of Florence, Florence, Italy \\ ${ }^{4}$ Department of Pharmacology and Physiology Saint Louis University, Saint Louis, Missouri, United States \\ *These authors contributed equally to this work \\ Correspondence to: Jacopo Junio Valerio Branca, email: jacopojuniovalerio.branca@unifi.it \\ Alessandra Pacini, email: alessandra.pacini@unifi.it \\ Keywords: blood brain barrier; RBE4 cell line; Oxaliplatin; tight junctions; neuropathic pain \\ Received: February 28, $2018 \quad$ Accepted: April 02, $2018 \quad$ Published: May 04, 2018 \\ Copyright: Branca et al. This is an open-access article distributed under the terms of the Creative Commons Attribution License \\ 3.0 (CC BY 3.0), which permits unrestricted use, distribution, and reproduction in any medium, provided the original author and \\ source are credited.
}

\section{ABSTRACT}

Oxaliplatin is a key drug in the treatment of advanced metastatic colorectal cancer. Despite its beneficial effects in tumor reduction, the most prevalent sideeffect of oxaliplatin treatment is a chemotherapy-induced neuropathy that frequently forces to discontinue the therapy. Indeed, along with direct damage to peripheral nerves, the chemotherapy-related neurotoxicity involves also the central nervous system (CNS) as demonstrated by pain chronicity and cognitive impairment (also known as chemobrain), a newly described pharmacological side effect.

The presence of the blood brain barrier (BBB) is instrumental in preventing the entry of the drug into the CNS; here we tested the hypothesis that oxaliplatin might enter the endothelial cells of the BBB vessels and trigger a signaling pathway that induce the disassembly of the tight junctions, the critical components of the BBB integrity.

By using a rat brain endothelial cell line (RBE4) we investigated the signaling pathway that ensued the entry of oxaliplatin within the cell. We found that the administration of $10 \mu \mathrm{M}$ oxaliplatin for 8 and $16 \mathrm{~h}$ induced alterations of the tight junction ( $\mathrm{TJs}$ ) proteins zonula occludens-1 (ZO-1) and of F-actin, thus highlighting BBB alteration. Furthermore, we reported that intracellular oxaliplatin rapidly induced increased levels of reactive oxygen species and endoplasmic reticulum stress, assessed by the evaluation of glucose-regulated protein GRP78 expression levels. These events were accompanied by activation of caspase- 3 that led to extracellular ATP release.

These findings suggested a possible novel mechanism of action for oxaliplatin toxicity that could explain, at least in part, the chemotherapy-related central effects. 


\section{INTRODUCTION}

Chemotherapy-induced neuropathy (CIN) is a frequent side effect for many of the most common cancer treatments and is predominantly characterized by sensory symptoms like pain, paresthesia and dysesthesia; motor and autonomic symptoms can develop dependently by the drug. CIN can be disabling, causing significant loss of functional abilities and decreasing quality of life [1]. The occurrence of CIN has been studied for decades and it is commonly associated with well-known anticancer drugs administration including oxaliplatin [2,3]. CIN is thought to be caused by drug-induced damage to components of the peripheral nervous system (PNS) and this structural damage results in abnormal somatosensory processing in the central nervous system (CNS) [4]. On the other hand, increasing evidence suggest a direct, neurotoxic effect of chemotherapeutics to the CNS. A remarkable reorganization of spinal and supraspinal areas after anticancer treatments was highlighted $[5,6]$. Accordingly, our group has demonstrated that during oxaliplatin-dependent neuropathic pain a significant increase in glial cells (microglia and astrocytes) $[7,8]$ as well as molecular, electrophysiological and redox alterations has been evidenced in spinal cord and many brain areas [9-11]. Furthermore, many studies have found evidence supporting the influence of chemotherapy on cognitive functioning [12-14], describing a new neuropsychological syndrome associated with cancer therapy named chemotherapy-induced cognitive impairment (CICI) or chemobrain characterized by memory, learning and motor function impairment [15-18].

Although many authors have demonstrated that the presence of the blood-brain barrier (BBB) limits access of many anticancer drugs to the brain and that the cerebrospinal fluid (CSF) penetration of the oxaliplatin is limited [19] a direct action of oxaliplatin on BBB endothelial cells (EC), the core element of BBB, could not be ruled out.

EC have been demonstrated to play a key role in BBB properties as they form the anatomic basis of the barrier $[20,21]$. These cells differ fundamentally from other vascular endothelia in their capacity to regulate the passage of molecules and cells to and from the neural parenchyma [22]. The capillary endothelium in the brain is tighter than peripheral microvessels, the cytoplasm has an uniform thickness with no fenestrae, and a continuous basement membrane [23, 24]. Most importantly, EC lining the vascular wall have narrow junctional complexes that includes mainly tight junction (TJ) and adherens junction (AJ) proteins $[25,26]$. They eliminate gaps or spaces between cells and prevent any free diffusion of bloodborne substances into the brain parenchymal space [27]. Neurotoxics may evoke strong or subtler mechanisms leading to $\mathrm{BBB}$ disruption or dysfunction. Increased cerebrovascular permeability can be implemented via the paracellular or the transcellular route, or both [28]. Several molecular mechanisms participate to the dysregulation of interendothelial junctions: inflammatory factors such as TNF- $\alpha$, IL-1 $\beta$, IL- 6 , or free radicals, or bradykinin, or angiogenic factors such as VEGF [29-31]. These factors, strongly related to chemotherapy-induced neurotoxicity, can mediate a downregulation of junctional proteins as well as subcellular redistribution, cytoskeletal rearrangements and a direct disruption of interendothelial junctions. Thus, it was our purpose to identify oxaliplatin cytotoxic profile and the molecular pathway related to oxaliplatin-dependent BBB alteration in an immortalized rat brain endothelial cell line (RBE4 cells) that, retaining a stable phenotype of BBB endothelium in vivo, are a ductile and widely accepted in vitro model for the study of the BBB [32].

\section{RESULTS}

\section{MTT assay}

Results from the cytotoxicity assays are represented in Figure 1. A concentration range of oxaliplatin from 1 to $100 \mu \mathrm{M}$ was tested at different time points $(8,16$ and 24 hours). Results show that oxaliplatin was able to induce a decrease in cell viability in a dose- and time-dependent manner. The drug starts to alter the metabolic activity of RBE4 cells after $8 \mathrm{~h}$ (Figure 1, triangles) of treatment. The lowest tested concentration $(1 \mu \mathrm{M})$ did not alter cell viability at any time point, whereas an oxaliplatin concentration of $3 \mu \mathrm{M}$ induced a significant $\left({ }^{*} p<0.05\right.$ vs control) decrease in cell viability only at $24 \mathrm{~h}$ (Figure 1, circles). On the contrary, at all time points significant $\left({ }^{*} p\right.$ $<0.05$ vs control) effects on RBE4 cells were observed at the highest concentration $(100 \mu \mathrm{M})$. In the concentration range between $3 \mu \mathrm{M}$ and $100 \mu \mathrm{M}$, cells exhibited a significant $\left({ }^{*} p<0.05\right.$ vs control) and strong decrease in cell viability at 16 (Figure 1, squares) and 24 hours (Figure 1, circles) after oxaliplatin treatment.

Based on previously reported data concerning patients' plasma concentration after oxaliplatin repeated treatments [35-37], we adopted the best experimental conditions that could better reflect an in vivo situation, mimicking chronic neuropathy. For this reason, we chose the concentration of $10 \mu \mathrm{M}$ that induced a low level of mortality but, at the same time, enabled us to study the oxaliplatin effects at the cellular level.

Moreover, to ensure that the concentration of oxaliplatin $10 \mu \mathrm{M}$ did not trigger the apoptotic pathway, we tested the expression levels of the pro-apoptotic protein BAX (Figure 2). The results showed that there was a significant $\left({ }^{*} p<0.05\right.$ vs control) increase in the protein levels only at the concentration of $30 \mu \mathrm{M}$ and after $24 \mathrm{~h}$ of exposure to the chemotherapeutic agent. 


\section{Immunocytochemistry for ZO-1 and F-actin proteins}

The results related to BAX protein expression levels, prompted us to determine the effects of $10 \mu \mathrm{M}$ of oxaliplatin on the expression and localization of ZO-1 and F-actin proteins on RBE4 cells at 8 and 16 hours posttreatment using immunohistochemistry. We found that the TJ protein ZO-1 localized to the cell-cell junctions, showing a more prominent and clear immunostaining at the cell contacts (Figure 3A, control), as well as F-actin exhibited a typical, marginal pattern of localization (Figure 3B, control). Eight hours of oxaliplatin treatment caused monolayer disruption, loss of ZO-1 staining, leading to a "zipper-like" staining pattern (Figure 3A, oxaliplatin) and holes that became visible between RBE4 cells, as well as the formation of numerous F-actin stress fibers instead of marginal localization (Figure 3B, oxaliplatin). These alterations were even more evident after 16 hours of treatment.

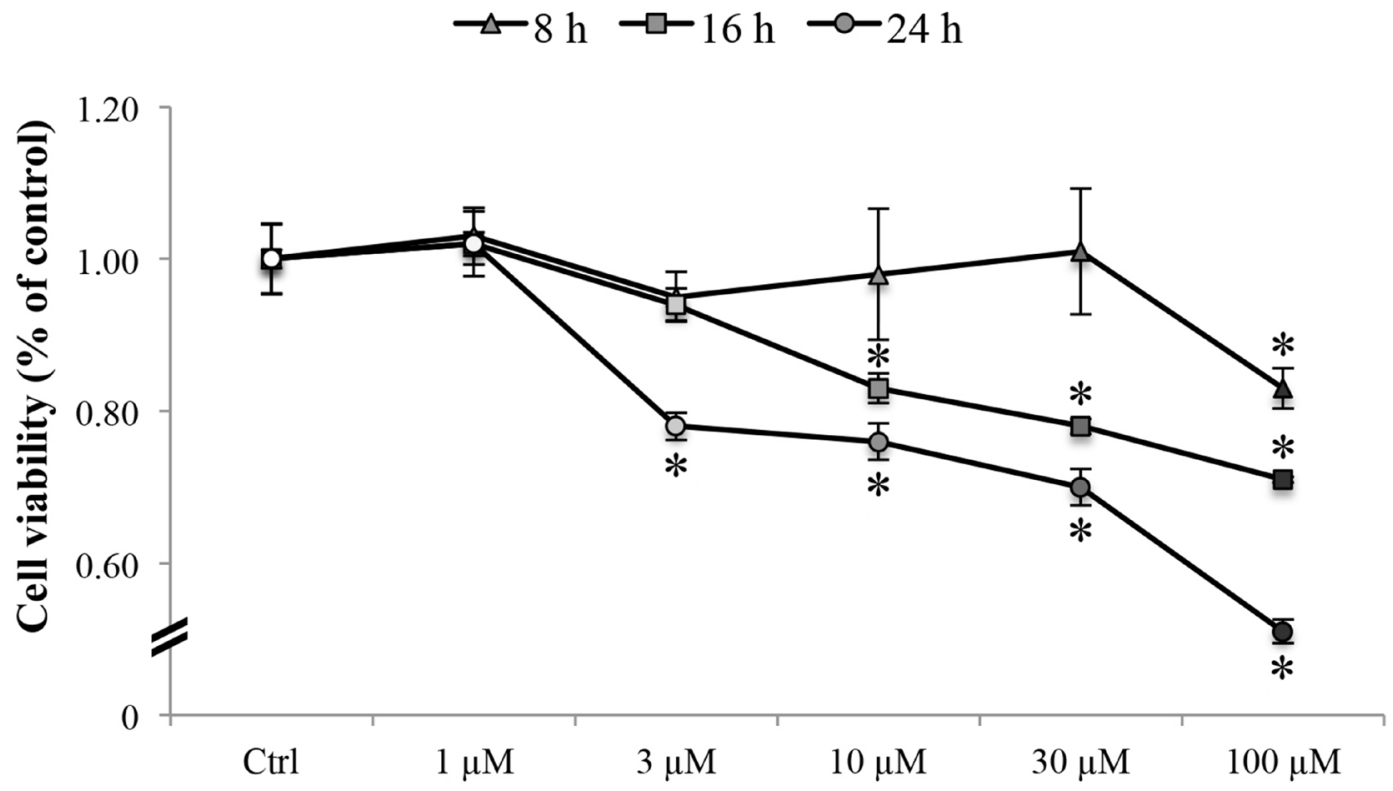

Figure 1: RBE4 cell viability. RBE4 cells $\left(2.5 \times 10^{4}\right.$ cells/well $)$ were incubated with oxaliplatin $(1-100 \mu \mathrm{M})$ for 8,16 or $24 \mathrm{~h}$. Viability was quantified by MTT assay; absorbance was measured at $570 \mathrm{~nm}$. Values are expressed in percentage of control absorbance as the mean \pm S.E.M. of five independent experiments. Control condition absorbance was fixed at $100 \%$. ${ }^{*} p<0.05$ vs control.

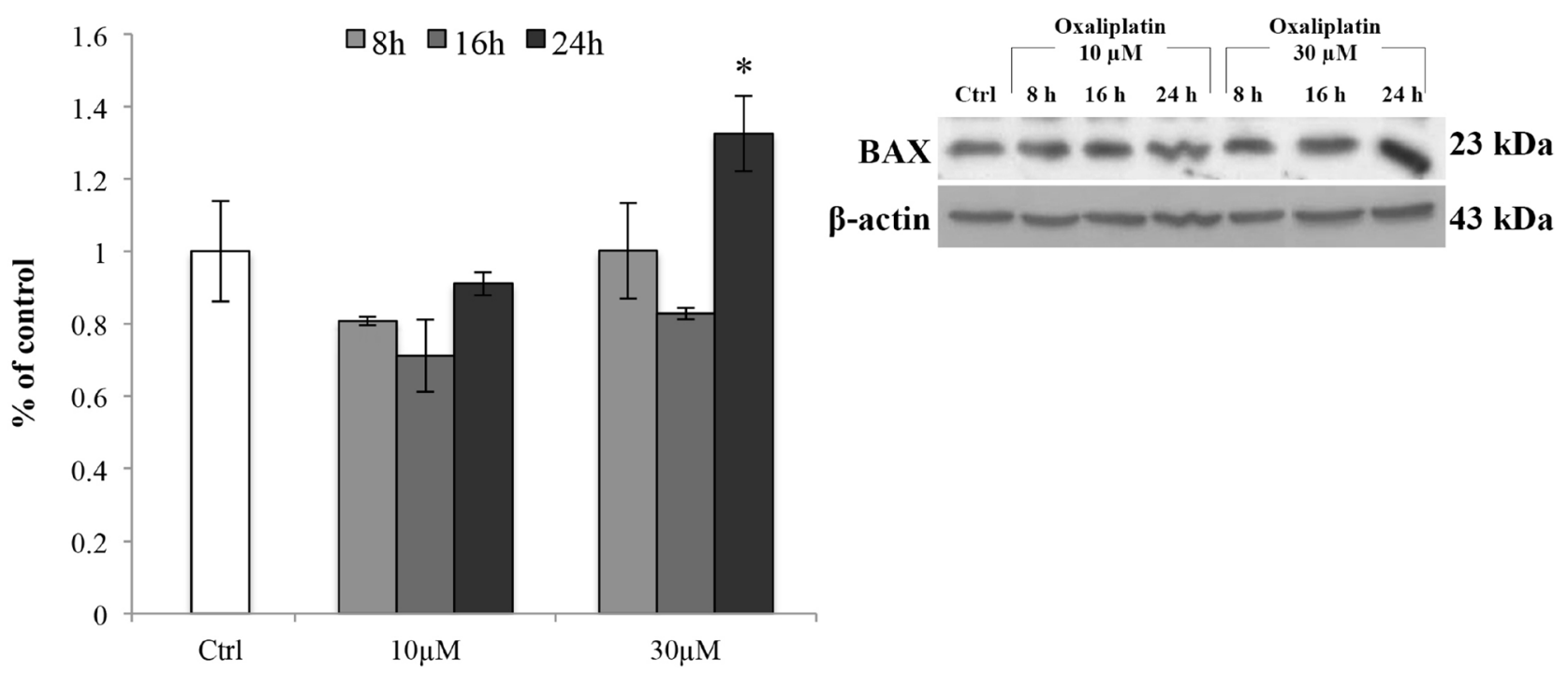

Figure 2: BAX protein expression levels. Representative Western blot of the effects of oxaliplatin $(10$ and $30 \mu \mathrm{M})$ on the protein levels of BAX after 8, 16 and 24 h of treatment. Bars represent the mean \pm S.E.M., $n=4 ;{ }^{*} p<0.05$ vs control (untreated cells). 


\section{Oxaliplatin-induced overproduction of intracellular ROS}

In order to evaluate the role of oxidative stress in $\mathrm{TJ}$ alterations, we measured the intracellular ROS in RBE4 cells at different time points after $10 \mu \mathrm{M}$ of oxaliplatin using the redox-sensitive fluoroprobe dye $\mathrm{CM}-\mathrm{H}_{2}$ DCFDA by FACS (fluorescence-activated cell sorting) analysis, as previously reported [38]. As shown in Figure 4, an increase in ROS production was seen following incubation of cells with $10 \mu \mathrm{M}$ oxaliplatin for 1 and 2 hours, which remain significantly increased at 4 hours compared to control cells ( ${ }^{*} p<0.05$ vs control). The ROS levels decreased quickly, and then returned to normalcy after $6 \mathrm{~h}$ of treatment $\left({ }^{\#} p<0.05\right.$ vs $\left.1 \mathrm{~h}\right)$, indicating that the increase of ROS generation was rapid and transient.

\section{Oxaliplatin-induced endoplasmic reticulum (ER) stress in RBE4 cells}

We then assessed whether the ROS increase induced ER stress. To this end, we evaluated GRP78 protein expression levels in RBE4 cells treated with 10 $\mu \mathrm{M}$ oxaliplatin for 8 and $16 \mathrm{~h}$ by immunoblot analysis on total cellular homogenates. Values were normalized to $\beta$-actin protein expression. As shown in Figure 5, $10 \mu \mathrm{M}$ oxaliplatin significantly ( ${ }^{*} p<0.05$ vs control) up-regulated GRP78 about three times compared to the control cells (Figure 5, light grey bar) at $8 \mathrm{~h}$ after the chemotherapy administration. This effect was time-dependent because the protein expression decreased (Figure 5, dark grey bar) to values comparable to that of control cells at $16 \mathrm{~h}$ of oxaliplatin treatment ( ${ }^{\wedge} p<0.05$ vs 8 h).

Taken together, these data indicated that after oxaliplatin treatment RBE4 cells underwent ER stress.

\section{Oxaliplatin treatment elicits caspase- 3 activation}

Considering that ER stress can induce the activation of caspase-3 [39], we checked the activation of this downstream signal of ER stress evaluating the caspase-3 enzymatic activity (Figure 6A) in the oxaliplatin-treated RBE4 cells using the EnzChek ${ }^{\circledR}$ Caspase-3 Assay Kit. We found that oxaliplatin significantly ( ${ }^{*} p<0.05$ vs control) activated the caspase 3 at $8 \mathrm{~h}$ of treatment (Figure 6A, light grey bar). Also, oxaliplatin-activated caspase-3 reaction was confirmed by Western blot assay (Figure 6B, light grey bar) showing an upregulation of the cleaved form of the protease. Moreover, in Figure 6A the result showed a time-dependent increase of caspase-3 activity that at $16 \mathrm{~h}$ of oxaliplatin treatment returned to control levels ( ${ }^{\wedge} p<0.05$ vs 8 h) (Figure 6A, dark grey bar).

\section{Oxaliplatin-dependent extracellular ATP release}

To characterize if RBE4 cells extrude ATP in response to oxaliplatin and eventually the mechanisms through which it occurs, firstly we evaluated the

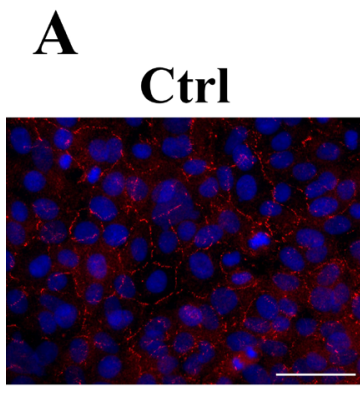

B

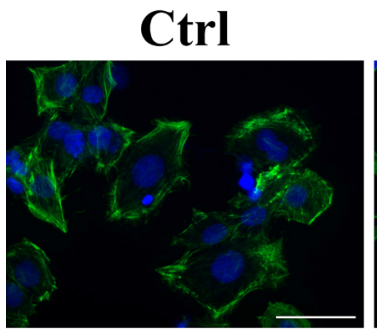

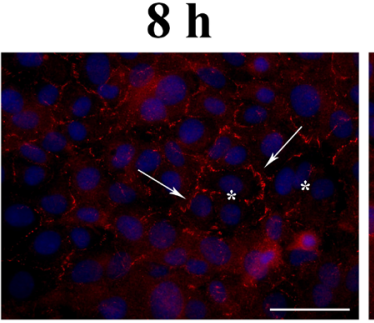

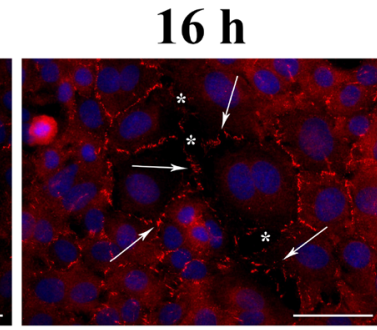

\section{Oxaliplatin $10 \mu \mathrm{M}$}
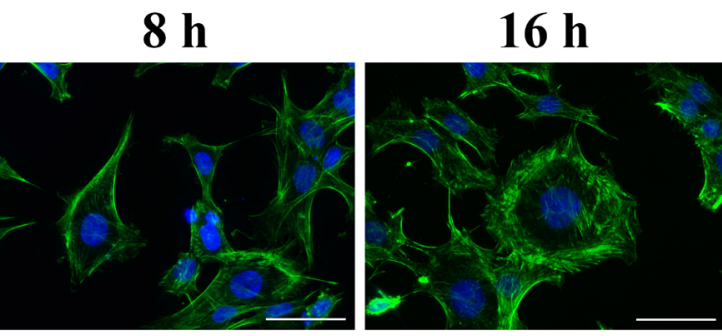

Oxaliplatin $10 \mu \mathrm{M}$

Figure 3: Effect of oxaliplatin on immunostaining for ZO-1 junctional protein and F-actin in RBE4 cells. In (A) asterisks show holes formed between endothelial cells. Arrows indicate fragmentation, indicative for loss of junctional immunostaining. Figure (B) shows the oxaliplatin-dependent appearance of numerous stress fibers. Original magnification $400 \times$. Bar: $50 \mu \mathrm{m}$. Each experimental point was performed in triplicate, for three different set of experiments. Pictures are representative of fifteen field captured for each experimental point. 
extracellular ATP release in RBE4 cells that underwent $10 \mu \mathrm{M}$ oxaliplatin treatment. In cultures exposed for 8 $\mathrm{h}$ to oxaliplatin, baseline ATP release was significantly $\left({ }^{*} p<0.05\right.$ vs control) elevated as compared with control cells (Figure 7, light grey bar). The phenomenon was transient since after $16 \mathrm{~h}$ of treatment with the chemotherapy agent the ATP levels returned to values comparable to those of control cells ( ${ }^{\wedge} p<0.05$ vs $\left.8 \mathrm{~h}\right)$ (Figure 7, dark grey bars).

\section{Oxaliplatin-dependent ATP release is PANX1 independent}

In order to verify if ATP release is dependent on pannexin-1 (PANX1) activation, we decided to examine whether RBE4 cells express PANX1 by immunoblot analysis. Figure 8A shows that RBE4 cells clearly expressed anti-PANX1 $(\sim 55 \mathrm{kDa})$ immunoreactivity in relatively high density as compared to $\beta$-actin standard protein levels.
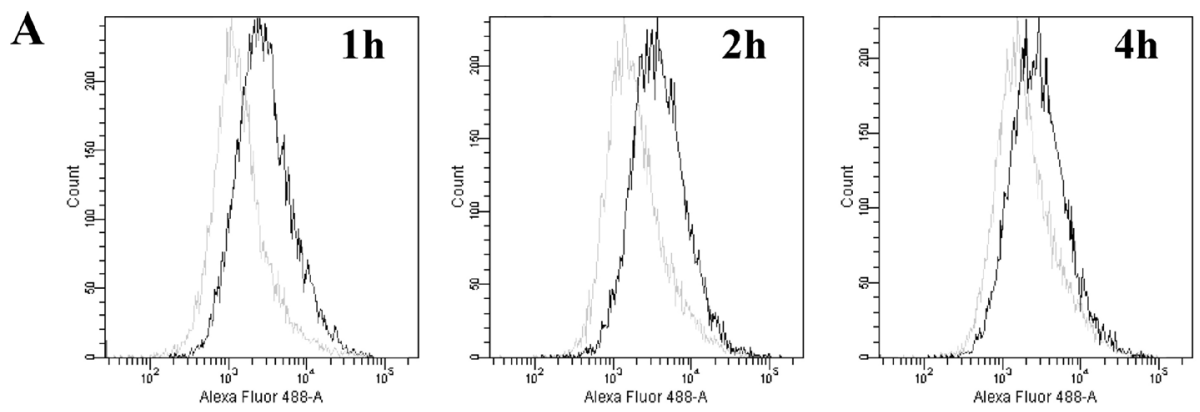

\section{$\square$ Control $\square$ Oxa $10 \mu \mathrm{M}$}
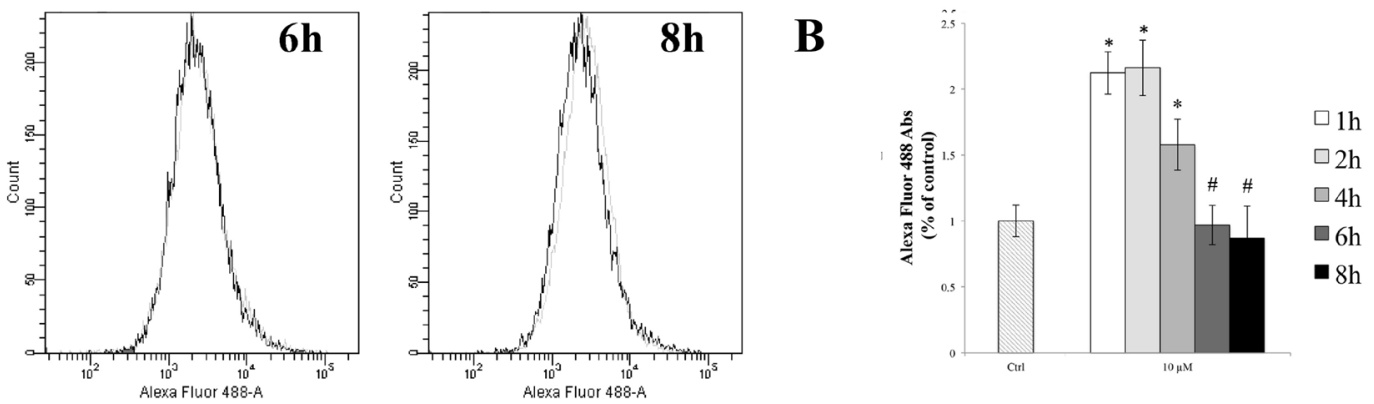

Figure 4: Evaluation of ROS generation. (A) Time-course of ROS production by $\mathrm{H}_{2}$ DCFDA fluorescence in control and in 10 $\mu \mathrm{M}$ oxaliplatin-treated RBE4 cells by FACS analysis. (B) The reported values (mean \pm S.E.M.) are representative of five independent experiments, each performed in triplicate; ${ }^{*} p<0.05$ vs control; ${ }^{\#} p<0.05$ vs $1 \mathrm{~h}$.

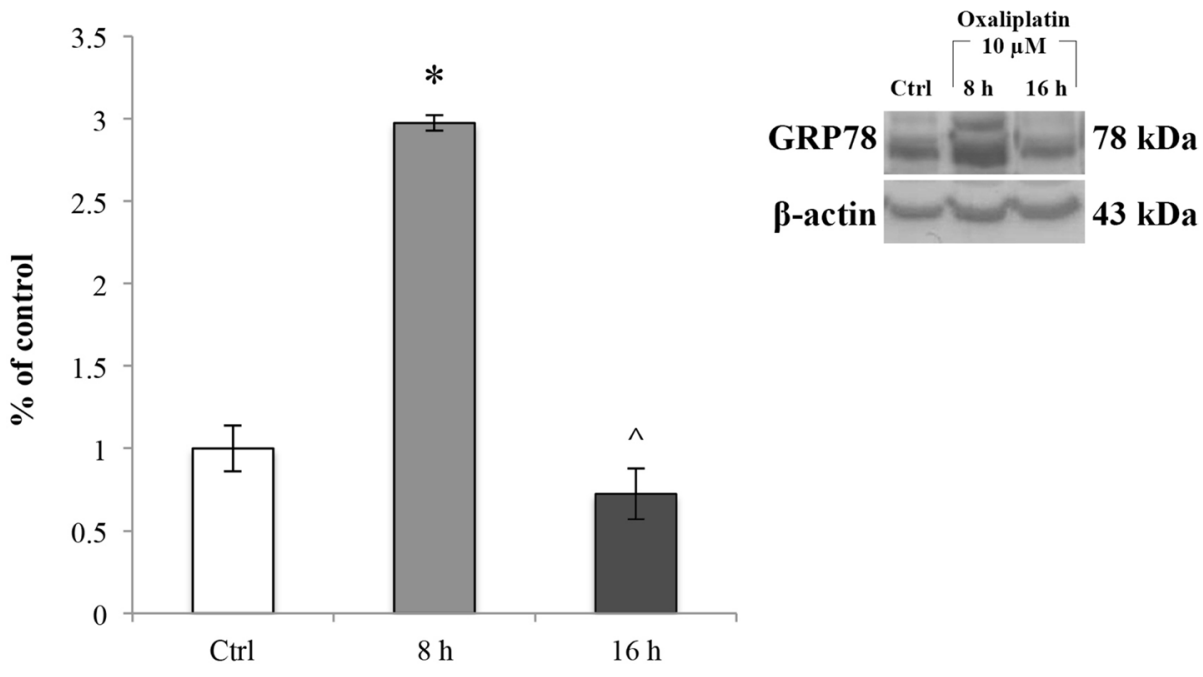

Figure 5: GRP78 expression levels in RBE4 cells treated with oxaliplatin. Immunoblot analysis at 8 and $16 \mathrm{~h}$ exposure to $10 \mu \mathrm{M}$ oxaliplatin and quantification of GRP78 expression at 8 and $16 \mathrm{~h}$. Control condition was arbitrarily set as $100 \%$ and results are expressed as mean \pm S.E.M. Results are representative of at least three independent immunoblots. Significant at ${ }^{*} p<0.05$ vs control and ${ }^{\wedge} p<0.05$ vs $8 \mathrm{~h}$. 
The role for PANX1 in ATP release in RBE4 cells was then examined. RBE4 cells were treated with oxaliplatin for 8 and $16 \mathrm{~h}$, and ATP extrusion was measured in the presence and absence of the selective PANX1 inhibitor ${ }^{10} \mathrm{Panx}$. We observed that the pretreatment with ${ }^{10} \mathrm{Panx}$ did not result in significantly blunt oxaliplatin-dependent ATP release (Figure 8B).
Finally we assessed whether caspase-3 induced PANX1 opening in RBE4 cells by evaluating ATP release after treatment with the AC-DEVD-CHO caspase-3 inhibitor. Results (Figure $8 \mathrm{C}$ ) showed that the application of AC-DEVD-CHO did not attenuate the ATP extrusion.

Since neither the pharmacological inhibition of PANX1 nor the caspase-3 inhibition did not prevent the
A

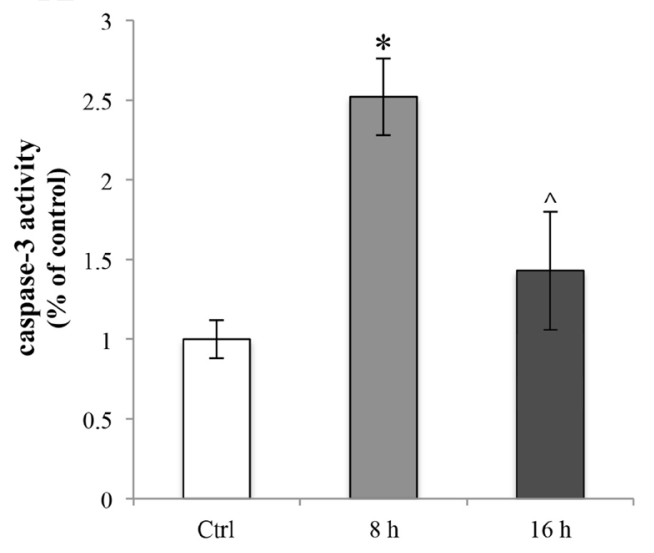

B

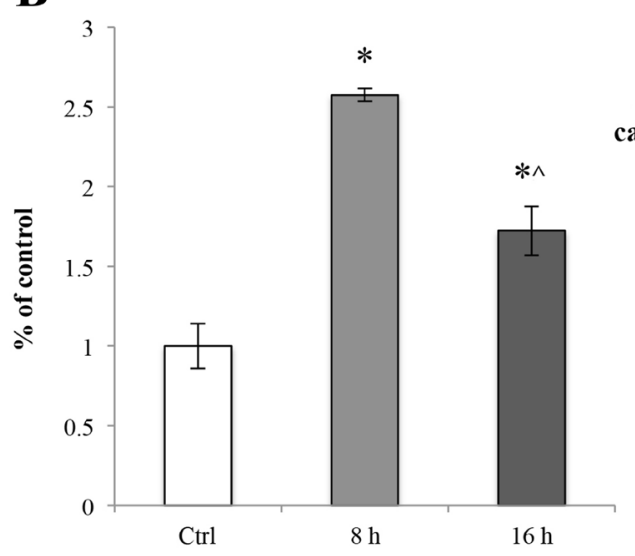

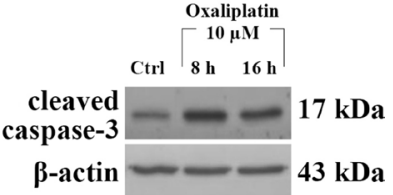

$43 \mathrm{kDa}$

Figure 6: Caspase-3 activity in RBE4 cell after oxaliplatin treatment. (A) Caspase-3 activity, revealed by fluorogenic peptidebased assay and (B). upregulation of caspase-3 cleavage, revealed by Western blot assay in RBE4 cells, post $10 \mu \mathrm{M}$ oxaliplatin treatment for 8 and $16 \mathrm{~h}$. $\beta$-actin was used as an internal control. Control condition was arbitrarily set as $100 \%$ and results are expressed as mean \pm S.E.M. All oxaliplatin treatment experiments were conducted independently in triplicate. Significant at ${ }^{*} p<0.05$ vs control and ${ }^{\wedge} p<0.05$ vs $8 \mathrm{~h}$.

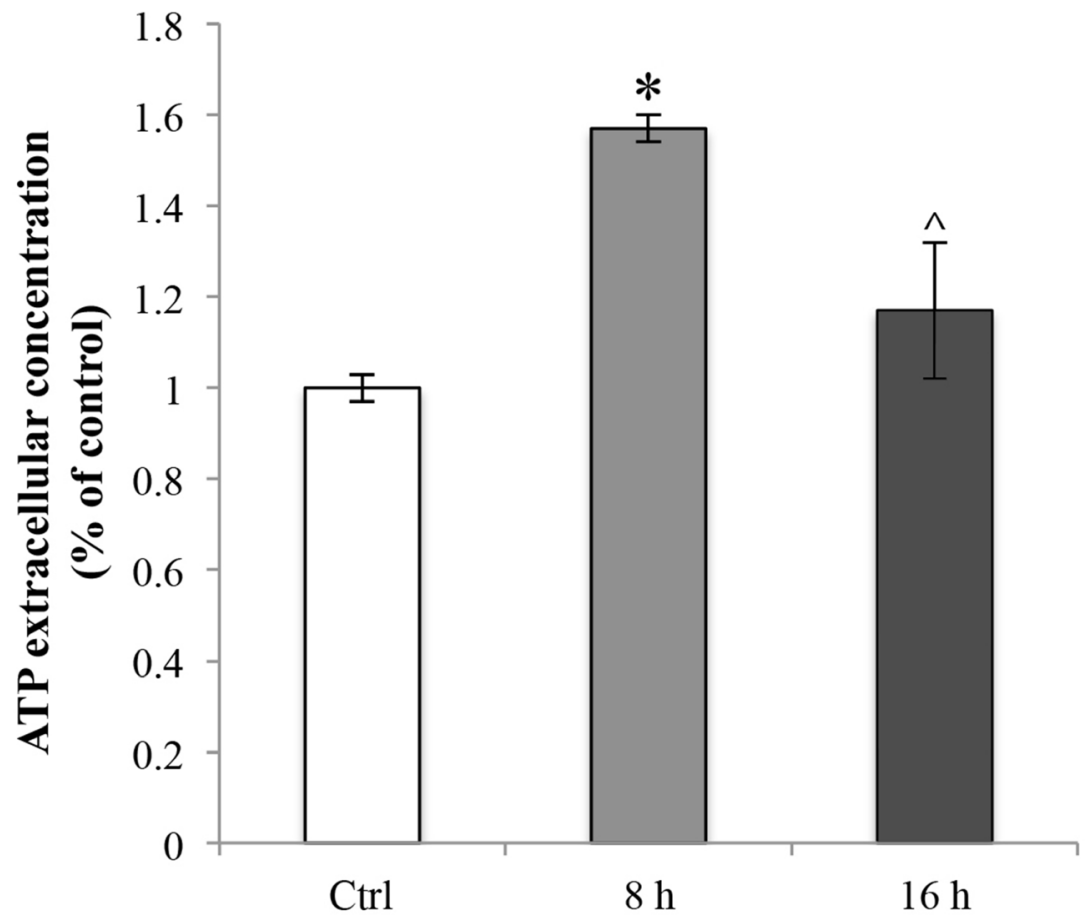

Figure 7: Oxaliplatin-dependent release of ATP. Extracellular ATP release from RBE4 cells in the presence of $10 \mu \mathrm{M}$ oxaliplatin. Control condition was arbitrarily set as $100 \%$ and results are expressed as mean \pm S.E.M. $n=3,{ }^{*} p<0.05$ vs control; ${ }^{\wedge} p<0.05$ vs 8 h. All oxaliplatin treatment experiments were conducted independently in triplicate. 
ATP spillage, we interpreted these data as showing that PANX1-mediated ATP release was not responsible for the ATP extrusion.

\section{DISCUSSION}

To study the mechanisms involved in the generation of oxaliplatin neurotoxicity, we have explored the specific cellular and molecular processes underlying the blood brain barrier endothelial cells events that occur in the presence of the anticancer drug. Using a rat brain endothelial cell line (RBE4 cells), we demonstrated that oxaliplatin administration caused significant changes in the junctional and cytoskeletal apparatus of endothelial cells, thus reducing their tightness. These oxaliplatindependent alteration of the BBB could be, at least in part, associated with higher distribution of molecules that cross a defective $\mathrm{BBB}$, and act in the CNS cooperating in pain chronicization.

Our data are in accordance with reported evidence that BBB, BSCB (Blood Spinal Cord Barrier), and BNB (Blood Nerve Barrier) disruptions participate in the complex mechanisms that initiate or maintain neuropathic pain [40-43].

Data concerning the mechanism of endothelial cellular uptake of oxaliplatin that is strictly dependent on the OCT2 (Organic Cation Transporter) [34], as well as the presence of these channels on the RBE4 plasma membrane [33] let us to hypothesized a direct interaction between oxaliplatin and BBB endothelial cells. Once inside the cells, oxaliplatin triggers an intracellular signaling pathway that results in a transient and reversible alteration (a sort of loosening) of the barrier itself.

Special characteristics of RBE4 cells include the presence of tight junctions. Structurally, the interendothelial tight junction complexes comprising the membrane proteins occludin and claudins and membranedirected scaffolding proteins, such as ZO-1, contribute to the physical barrier nature of $\mathrm{BBB}$ and strictly limit the molecular/cellular influx from circulation [44]. Moreover, ZO-1 serves to anchor tight junctions (TJs) to the actin cytoskeleton in the cell [45-47] and F-actin has a critical role in establishing inter-endothelial junctional integrity and defining the peripheral morphological belt of endothelial cells $[48,49]$. The re-distribution of major $\mathrm{TJ}$ proteins can result in reduced endothelial barrier tightness [50]. We evaluated the TJ protein $\mathrm{ZO}-1$ and the cytoskeletal F-actin in order to evidence oxaliplatininduced physiopathologic alteration. As a result, we found that oxaliplatin induced the dislocation of ZO-1 and the formation of F-actin stress fibers.

Previous studies have shown the important role of oxidative stress in the toxicity of oxaliplatin $[11,37,51-53]$. An excessive production of ROS can alter endothelial cells integrity by cytoskeletal rearrangements and redistribution of TJ proteins, triggering a loss of cellular interaction and increasing their permeability [54-57]. We therefore hypothesized that oxaliplatin, once entered the endothelial cells by OCT2 might have an effect on ROS production, which could possibly be accompanied by TJ dislocation. In the present study, it has shown that oxaliplatin induced a time-dependent increase in ROS production, indicating that oxaliplatin-dependent oxidative stress could be an important signal involved in the disruption of the integrity of the endothelial junctional apparatus.

In response to oxidative stress mediated by ROS, accumulation of unfolded or misfolded proteins triggers the cellular adaptive procedure known as ER stress $[58,59]$. By mediating the shutdown of general protein synthesis and increasing the production of molecular chaperones, including glucose-regulated protein 78 (GRP78), ER stress is designed to be protective [60-63]. Recently, ER stress has been shown to play a detrimental role on TJs integrity [64]. In fact, ER stress can also accelerate ROS production both in the ER and mitochondria [65-67], that in turn activate apoptotic signaling pathway $[68,69]$. Considering that in our
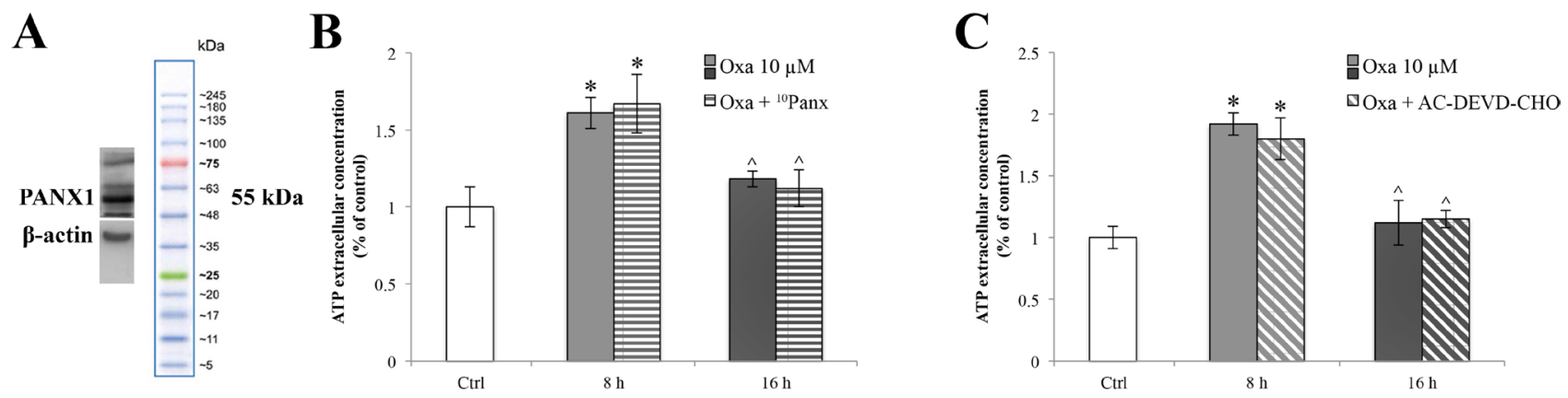

Figure 8: PANX1 channels expression in RBE4 cells and release of ATP during oxaliplatin treatment with ${ }^{10}$ Panx and AC-DEVD-CHO. Western blot densitometry analysis of PANX1 protein expression levels in RBE4 cells (A). ATP quantification assay performed in the presence of $100 \mu \mathrm{M}$ of ${ }^{10} \mathrm{Panx}$ (B), or $100 \mu \mathrm{M}$ AC-DEVD-CHO (C) demonstrating that both PANX1 and caspase-3 inhibitors did not affect the ATP release. Assays were performed in triplicate. Data are expressed as mean \pm S.E.M. Data are representative of three independent experiments. ${ }^{*} p<0.05$ vs control; $\wedge p<0.05$ vs $8 \mathrm{~h}$. 
condition the mitochondria-dependent pro-apoptotic protein BAX was not activated, we decided to investigate the changes in GRP78 expression levels. Our findings showed that GRP78 is induced in a time-dependent manner, suggesting that ER stress is activated at $8 \mathrm{~h}$ after oxaliplatin treatment and that ROS could be the initiator of the ER stress.

It is well known [63, 64, 66-70] that the ER stress response is a mechanism that the cell puts in place in order to react to perturbations in ER homeostasis, during which GRP78 functions as a cytoprotective protein. Thus, the oxaliplatin-dependent upregulation of GRP78 could be to relieve the ER stress and restore cell function. It has been also suggested that the caspase- 3 activation is one of the mechanisms that operate such protection, recognizing and removing overproduced ROS [71-74]. According to these data, our results showed an oxaliplatin-dependent activation of caspase- 3 in absence of a parallel activation of the apoptotic signalling cascade (demonstrated by the lack of an increase in BAX protein expression levels). On the other hand, other authors have demonstrated that caspase-3, cleaving the PANX1 autoinhibitory C-terminal domain, induces the functional activation of PANX1 [75], a channel known to have a prominent role in the release of ATP [53, 76]. Indeed, recent findings revealed that chemotherapeutic drugs induce ATP release [77] that, in turn, leads to degradation of tight junctions, such as ZO-1 [78]. Furthermore, Boyd-Tressler and co-authors have fully demonstrated that diverse chemotherapy agents, induce functional activation of PANX1 [10, 79]. Driven by these results, we hypothesized that oxaliplatindependent caspase-3 activation could elicit an ATP spillage by PANX1 channels. To our knowledge this work demonstrates for the first time that RBE4 cells express PANX1 channels, confirming previous data showing that these cells are a useful in vitro model to study the BBB $[32,80]$. Moreover, we demonstrated that oxaliplatin induces an ATP release and that this leakage is independent of the PANX1 opening. This result is not surprising since the caspase-3-mediated mechanism of PANX1 activation is closely related to the onset of the apoptotic pathway [81], a condition that does not occur in our experimental condition.

Moreover, this data agrees with the maintenance of ATP release in the presence of a caspase- 3 inhibition. A possible, early, homeostatic signaling mediated by caspase-3 activation is suggested. By contrast, the cellular mediator able to evoke the release of the excitotoxic molecule ATP remains unclear deserving further research.

In summary, our data provide evidence of a chemotherapy-dependent BBB alterations that, starting from ROS formation, activates the ER stress/ATP release signalling pathway in RBE4 cells. We have conclusively shown that activation of this pathway, causes alterations of the TJ protein ZO-1 and of the cytoskeletal protein
F-actin. These findings contribute to identify the signal pathways of chemotherapy-induced opening of the BBB and emphasizes the importance of dissecting in detail the molecular mechanism that alters the BBB during chemotherapy treatment in order to establish potential therapeutic targets in the treatment of chronic pain management.

\section{MATERIALS AND METHODS}

\section{Cell culture and treatments}

The rat brain endothelial cell line RBE4 was kindly provided by Dr Vincenzo Giuseppe Nicoletti (Department of Biomedical Sciences, University of Catania, Italy). Cells (up to passage 20) were grown and maintained in alpha-minimal essential medium (alpha-MEM)/Ham's F10 (1:1) (GIBCO, Thermo Fisher Scientific, Milan, Italy) supplemented with $10 \%$ fetal bovine serum (FBS), 1\% penicillin/streptomycin, $2 \mathrm{mM}$ L-glutamine (EuroClone, Milano, Italy) and $1 \mathrm{ng} / \mathrm{ml}$ basic fibroblast growth factor (bFGF) (Thermo Fisher Scientific, Milano, Italy) at $37^{\circ} \mathrm{C}$, $5 \% \mathrm{CO}_{2}$ in humidified atmosphere. The growth medium was routinely changed 2-3 times per week. For each experimental set-up, the cells were seeded on appropriate support for $24 \mathrm{~h}$ in complete growth medium. The day of the stimulation, the complete growth medium was replaced with starvation medium (without FBS and without bFGF) containing appropriate stimuli at different concentration.

${ }^{10}$ Panx (Proteogenix, Schiltigheim, France) was dissolved in 1\% DMSO (dimethyl sulfoxide) to obtain 1 $\mathrm{mM}$ solution and then diluted in physiological medium at final concentration of $100 \mu \mathrm{M}$ in the presence of oxaliplatin for 8 or $16 \mathrm{~h}$. This concentration was chosen accordingly with previous published data [10, 82, 83]. The caspase-3 inhibitor AC-DEVD-CHO (N-Ac-Asp-GluVal-Asp-CHO) (Calbiochem, Milan, Italy) was incubated for 2 hours at a concentration of $100 \mu \mathrm{M}$ before oxaliplatin treatment. A non-toxic effect of AC-DEVD-CHO at this concentration has been demonstrated previously [65].

\section{MTT assay}

Cell viability was evaluated by the reduction of 3-(4,5-di-methylthiozol-2-yl)-2,5-diphenyltetrazolium bromide (MTT) by mitochondrial dehydrogenase, that directly reflects the activity of mitochondria, and can be considered an indirect measurement of cell viability. RBE4 cells were plated into 96 multiwell plates, at the density of $2.5 \times 10^{4}$ cells/well, in their appropriate complete growth medium. The following day, the cells were starved as described above and treated with different concentrations of oxaliplatin (1-3-10-30-100 $\mu \mathrm{M})$, for 8, 16 and $24 \mathrm{~h}$. After treatment, the starvation medium containing stimuli was removed and substituted with $1 \mathrm{mg} / \mathrm{mL} \mathrm{MTT} \mathrm{(in} \mathrm{starvation}$ 
medium without phenol red). The chromogenic solution was incubated for at least $20 \mathrm{~min}$. at $37^{\circ} \mathrm{C}$. The formazan crystals formed were dissolved by adding $100 \mu \mathrm{l}$ of DMSO in each well and the absorption at $570 \mathrm{~nm}$ was read using a microplate reader (MultiskanFC ${ }^{\mathrm{TM}}$ microplate photometer, ThermoFisher Scientific, Milan, Italy). Each experimental point was performed in quintuplicate, for three times.

\section{Western blotting}

RBE4 cells, at the density of $3.5 \times 10^{6}$ cells, were plated in Petri dishes in their appropriate complete growth medium. After $24 \mathrm{~h}$ the cells were serum starved and stimulated with oxaliplatin 10-30 $\mu \mathrm{M}$, for 8,16 , and 24 h. After treatments, the medium was removed and cells were scraped in cold PBS (Phosphate Buffer Saline). The cell suspensions were centrifuged at room temperature (RT) for $10 \mathrm{~min}$. at $1000 \mathrm{rpm}$. The pellets obtained were treated with Mem-PER ${ }^{\mathrm{TM}}$ Plus Membrane Protein Extraction Kit (Thermo Fisher Scientific, Milan, Italy) following the manufacture instruction, to isolate the integral and attached membrane proteins isolated from the cytosolic proteins. The protein concentration was evaluated by the Bradford method and equal amounts of protein $(15 \mu \mathrm{g})$ were separated on a $12 \%$ polyacrylamide gel by electrophoreses and transferred onto nitrocellulose membrane (Porablot NPC, MACHEREY-NAGEL, Milan, Italy). After $1 \mathrm{~h}$ blocking with $3 \%$ bovine serum albumin (BSA) in Trisbuffered saline containing $0.1 \%$ Tween 20 (Tween-TBS) at RT, the blots were incubated in Tween-TBS $/ 3 \%$ BSA overnight at $4^{\circ} \mathrm{C}$ with the following primary antibodies; rabbit primary antibody for $78 \mathrm{kDa}$ glucose-regulated protein (GRP78) (ThermoFisher Scientific, Milan, Italy), for cleaved caspase-3 (Cell Signalling, Euroclone, Milan, Italy), for BCL2 associated X protein (BAX) (Santa Cruz Biotechnology, Milan, Italy), and goat primary antibody for (PANX1) (Santa Cruz Biotechnology) at 1:500, 1:1000 and 1:300, and 1:500, respectively. After washing with TweenTBS, the goat anti-rabbit HRP secondary antibodies (Santa Cruz Biotechnology) was added at 1:5,000 dilution in Tween-TBS for $1 \mathrm{~h}$ at room temperature (RT), and washed again. Proteins were detected with the Amersham ECL Plus Western Blotting Detection Reagent (GE Healthcare, Milan, Italy). Protein expression levels were then quantified by the ImageJ analysis software (ImageJ, National Institute of Health, USA, http://imagej.nih.gov/ij). $\beta$-actin (1:10000 dilution) (Santa Cruz Biotechnology) normalization was performed for each sample. Each experiment was performed three times, in triplicate.

\section{ZO-1 tight junction and F-actin immunofluorescent labeling}

RBE4 cells were seeded on sterilized cover slips (lodged in a 6 multiwell plate) in the number of $1.5 \times 10^{5}$ cells, in their appropriate complete growth medium. After $24 \mathrm{~h}$ the cells were serum starved and stimulated with oxaliplatin $10-30 \mu \mathrm{M}$, for 8 , and $16 \mathrm{~h}$. After treatments, the medium was removed and each cover slip was washed twice with cold PBS followed by fixation with paraformaldehyde $3.7 \%$ (for F-actin) in $\mathrm{PBS}$ for $10 \mathrm{~min}$. at room temperature or cold methanol (for Zonula Occludens-1, ZO-1) for $20 \mathrm{~min}$. After fixation, two more washes with cold PBS were performed, the cover slips were dried at RT for at least $1 \mathrm{~h}$. The fixed cells where rinsed in cold PBS for three time and permeabilized with a $0.1 \%$ solution of TRITON X-100 in PBS for 10 min at RT. Following, cells were washed three times with PBS and then incubated for 15 min. in a blocking solution (1\% BSA in PBS) at RT. Each cover slip was incubated overnight at $4^{\circ} \mathrm{C}$ with the rabbit primary antibody anti-ZO1 (1:50) or with Alexa-488-conjugated phalloidin (F-actin) (1:200; ThermoFisher Scientific, Milan, Italy), in 1\% BSA. The day after, cells were washed three times with PBS and each cover slip was incubated in goat anti-rabbit (for ZO-1) immunoglobulin G ( $\mathrm{IgG}$ ) secondary antibody, conjugated with Alexa Fluor 568 (1:200; Invitrogen, Milan, Italy) for $1 \mathrm{~h}$ at RT. Then (for ZO-1 and F-actin) after counterstaining with DAPI (4',6-diamidin-2fenilindolo; 1:2000 dilution; Invitrogen, Milan, Italy) for $5 \mathrm{~min}$ at RT, cover slip glasses were mounted using Fluoromount anti-fade solution (ThermoFisher Scientific, Milan, Italy) on cover slides. Fluorescent signals were detected at $400 \times$ total magnification (five microscopic fields for each experimental point) by a motorized Leica DM6000B microscope equipped with a DFC350FX camera. Negative controls were performed by omitting the primary antibody to confirm the specificity of primary antibodies used and by omitting the second antibody to reveal autofluorescent labeling (data not shown). Fifteen pictures from each field were captured. The data shown represent the typical data from three independent experiments that yielded similar results. Each experiment was performed in triplicate.

\section{Quantification of intracellular ROS by flow cytometry}

RBE4 cells were plated in Petri dishes in their appropriate complete growth medium, reaching about $80 \%$ of confluence. After that, the cells were starved as reported above and stimulated with $10 \mu \mathrm{M}$ of oxaliplatin, for 1, 2, 4, 6 and $8 \mathrm{~h}$. After each treatments, cells where washed twice with DMEM w/o phenol red and detached from Petri dishes surface by trypsin/EDTA and centrifuged at $1000 \mathrm{rpm}$ for $5 \mathrm{~min}$. at room temperature. The pellets were gently resupended in DMEM w/o phenol red and labelled with $1 \mu \mathrm{M} \mathrm{CM}-\mathrm{H}_{2}$ DCFDA (Life Technologies, ThermoFisher Scientific, Milan, Italy). The tubes were gently mixed and dark incubated at $37^{\circ} \mathrm{C}$ for $20 \mathrm{~min}$. After labelling, cells were centrifuged again, the supernatant 
discard and the pellets obtained were gently resuspended in DMEM w/o phenol red, and immediately analyzed using a FACSCanto flow cytometer (Becton-Dickinson, San Jose, CA, USA).

The sample flow rate was adjusted to about $10^{3}$ cells $/ \mathrm{s}$. For a single analysis, the fluorescence properties of about $2.5 \times 10^{4} \mathrm{RBE} 4$ cells were collected. Each experiment was performed three times, in triplicate.

\section{Caspase-3 enzimatic activity}

RBE4 cells were plated in 6 -well plates $\left(5 \times 10^{5} /\right.$ well $)$ in appropriate complete growth medium. The following day, cells were starved and stimultated with oxaliplatin $10-30 \mu \mathrm{M}$ for 8 and $16 \mathrm{~h}$. After treatment, cells were scraped in $100 \mu \mathrm{l}$ lysis buffer $(200 \mathrm{mM}$ Tris- $\mathrm{HCl}$ buffer, $\mathrm{pH} 7.5$, containing $2 \mathrm{M} \mathrm{NaCl}, 20 \mathrm{mM}$ EDTA, and $0.2 \%$ Triton X-100). Fifty $\mu 1$ of the supernatants were incubated with $25 \mu \mathrm{M}$ fluorogenic peptide caspases 3 substrate rhodamine 110 bis-(N-CBZ-L-aspartyl-L-glutamyl-L-valyl-L-aspartic acid amide) (AC-DEVD-CHO; Molecular Probes) at $25^{\circ} \mathrm{C}$ for $30 \mathrm{~min}$. The amount of cleaved substrate in each sample was measured in a 96-well plate fluorescent spectrometer (Perkin-Elmer; excitation at $496 \mathrm{~nm}$ and emission at $520 \mathrm{~nm}$ ). Each experiment was performed three times, in triplicate.

\section{Extracellular ATP quantification}

RBE4 cells were plated in 6-well plates $\left(5 \times 10^{5}\right)$ well) in appropriate complete growth medium. The following day, cells were starved and stimultated with oxaliplatin $10-30 \mu \mathrm{M}$ for 8 and $16 \mathrm{~h}$. After treatment, the medium was harvested and $50 \mu \mathrm{l}$ were processed following the manufacture's procedure (ATPlite - Luminiscence ATP Detection Assay System, PerkinElmer Italia, Milan, Italy). The extracellular ATP was quantified by luminescence using a VICTOR microplate reader (PerkinElmer, Milan, Italy). Each experiment was performed three times, in triplicate.

\section{Statistical analysis}

Statistical analyses were performed by Twoway ANOVA followed by the Mann-Whitney test. All assessments were made by researchers blinded to treatments. Data were analysed using "Origin 9" software (OriginLab, Northampton, USA). Differences were considered significant at $p<0.05$.

\section{CONFLICTS OF INTEREST}

All authors declare that there are no conflicts of interest to disclose.

\section{REFERENCES}

1. Miltenburg NC, Boogerd W. Chemotherapy-induced neuropathy: A comprehensive survey. Cancer Treat Rev. 2014; 40:872-82.

2. Kroigard T, Schroder HD, Qvortrup C, Eckhoff L, Pfeiffer P, Gaist D, Sindrup SH. Characterization and diagnostic evaluation of chronic polyneuropathies induced by oxaliplatin and docetaxel comparing skin biopsy to quantitative sensory testing and nerve conduction studies. Eur J Neurol. 2014; 21:623-9.

3. de Carvalho Barbosa M, Kosturakis AK, Eng C, Wendelschafer-Crabb G, Kennedy WR, Simone DA, Wang XS, Cleeland CS, Dougherty PM. Quantitative sensory analysis of peripheral neuropathy produced by colorectal cancer and its exacerbation by cumulative dose of oxaliplatin chemotherapy. Cancer Res. 2014; 74:5955-62.

4. Bhagra A, Rao RD. Chemotherapy-induced neuropathy. Curr Oncol Rep. 2007; 9:290-9.

5. Nudelman KN, McDonald BC, Wang Y, Smith DJ, West JD, O'Neill DP, Zanville NR, Champion VL, Schneider BP, Saykin AJ. Cerebral perfusion and gray matter changes associated with chemotherapy-induced peripheral neuropathy. J Clin Oncol. 2016; 34:677-83.

6. Hu LY, Zhou Y, Cui WQ, Hu XM, Du LX, Mi WL, Chu YX, Wu GC, Wang YQ, Mao-Ying QL. Triggering receptor expressed on myeloid cells 2 (TREM2) dependent microglial activation promotes cisplatin-induced peripheral neuropathy in mice. Brain Behav Immun. 2018; 68:132-45.

7. Di Cesare Mannelli L, Pacini A, Bonaccini L, Zanardelli M, Mello T, Ghelardini C. Morphologic features and glial activation in rat oxaliplatin-dependent neuropathic pain. J Pain. 2013; 14:1585-600.

8. Di Cesare Mannelli L, Pacini A, Micheli L, Tani A, Zanardelli M, Ghelardini C. Glial role in oxaliplatininduced neuropathic pain. Exp Neurol. 2014; 261:22-33.

9. Di Cesare Mannelli L, Pacini A, Corti F, Boccella S, Luongo L, Esposito E, Cuzzocrea S, Maione S, Calignano A, Ghelardini C. Antineuropathic profile of $\mathrm{N}$-palmitoylethanolamine in a rat model of oxaliplatininduced neurotoxicity. PLoS One. 2015; 10:e128080.

10. Di Cesare Mannelli L, Marcoli M, Micheli L, Zanardelli M, Maura G, Ghelardini C, Cervetto C. Oxaliplatin evokes P2X7-dependent glutamate release in the cerebral cortex: A pain mechanism mediated by Pannexin 1 . Neuropharmacology. 2015; 97:133-41.

11. Di Cesare Mannelli L, Zanardelli M, Failli P, Ghelardini C. Oxaliplatin-induced neuropathy: oxidative stress as pathological mechanism. Protective effect of silibinin. J Pain. 2012; 13:276-84.

12. Silberfarb PM. Chemotherapy and cognitive defects in cancer patients. Annu Rev Med. 1983; 34:35-46. 
13. Dubois M, Lapinte N, Villier V, Lecointre C, Roy V, Tonon MC, Gandolfo P, Joly F, Hilber P, Castel H. Chemotherapyinduced long-term alteration of executive functions and hippocampal cell proliferation: role of glucose as adjuvant. Neuropharmacology. 2014; 79:234-48.

14. Lange M, Giffard B, Noal S, Rigal O, Kurtz JE, Heutte N, Lévy C, Allouache D, Rieux C, Le Fel J, Daireaux A, Clarisse B, Veyret C, et al. Baseline cognitive functions among elderly patients with localised breast cancer. Eur J Cancer. 2014; 50:2181-9.

15. Ahles TA, Saykin AJ. Candidate mechanisms for chemotherapy-induced cognitive changes. Nat Rev Cancer. 2007; 7:192-201.

16. Dietrich J, Prust M, Kaiser J. Chemotherapy, cognitive impairment and hippocampal toxicity. Neuroscience. 2015; 309:224-32.

17. Horky LL, Gerbaudo VH, Zaitsev A, Plesniak W, Hainer J, Govindarajulu U, Kikinis R, Dietrich J. Systemic chemotherapy decreases brain glucose metabolism. Ann Clin Transl Neurol. 2014; 1:788-98.

18. Janelsins MC, Kohli S, Mohile SG, Usuki K, Ahles TA, Morrow GR. An update on cancer- and chemotherapyrelated cognitive dysfunction: current status. Semin Oncol. 2011; 38:431-8.

19. Jacobs SS, Fox E, Dennie C, Morgan LB, McCully CL, Balis FM. Plasma and cerebrospinal fluid pharmacokinetics of intravenous oxaliplatin, cisplatin, and carboplatin in nonhuman primates. Clin Cancer Res. 2005; 11:1669-74.

20. Khan E. An examination of the blood-brain barrier in health and disease. Br J Nurs. 2005; 14:509-513.

21. Hawkins RA, O'Kane RL, Simpson IA, Vina JR. Structure of the blood 13; brain barrier and its role in the transport of amino acids. J Nutr.2006; 136:218S-226S.

22. Ge S, Song L, Pachter JS. Where is the blood-brain barrier ... really? J Neurosci Res. 2005; 79:421-27.

23. Abbott NJ. Astrocyte-endothelial interactions and bloodbrain barrier permeability. J Anat. 2002; 200:629-38.

24. de Boer AG, Gaillard PJ. Blood-brain barrier dysfunction and recovery. J Neural Transm. 2006; 113:455-62.

25. Hawkins BT, Davis TP. The blood-brain barrier/ neurovascular unit in health and disease. Pharmacol Rev. 2005; 57:173-85.

26. Luissint AC, Artus C, Glacial F, Ganeshamoorthy K, Couraud PO. Tight junctions at the blood brain barrier: physiological architecture and disease-associated dysregulation. Fluids Barriers CNS. 2012;9:23.

27. Weiss N, Miller F, Cazaubon S, Couraud PO. The bloodbrain barrier in brain homeostasis and neurological diseases. Biochim Biophys Acta. 2009; 1788:842-57.

28. Obermeier B, Verma A, Ransohoff RM. The blood-brain barrier. Handb Clin Neurol. 2016; 133:39-59.

29. Rochfort KD, Collins LE, Murphy RP, Cummins PM. Downregulation of blood-brain barrier phenotype by proinflammatory cytokines involves NADPH oxidase-dependent
ROS generation: consequences for interendothelial adherens and tight junctions. PLoS One. 2014; 9:e101815.

30. Argaw AT, Zhang Y, Snyder BJ, Zhao ML, Kopp N, Lee SC, Raine CS, Brosnan CF, John GR. IL-1beta regulates bloodbrain barrier permeability via reactivation of the hypoxiaangiogenesis program. J Immunol. 2006; 177:5574-84.

31. Morin-Brureau M, Lebrun A, Rousset MC, Fagni L, Bockaert J, de Bock F, Lerner-Natoli M. Epileptiform activity induces vascular remodeling and zonula occludens 1 downregulation in organotypic hippocampal cultures: role of VEGF signaling pathways. J Neurosci. 2011; 31:10677-88.

32. Roux F, Couraud PO. Rat brain endothelial cell lines for the study of blood-brain barrier permeability and transport functions. Cell Mol Neurobiol. 2005; 25:41-58.

33. Friedrich A, Prasad PD, Freyer D, Ganapathy V, Brust P. Molecular cloning and functional characterization of the OCTN2 transporter at the RBE4 cells, an in vitro model of the blood-brain barrier. Brain Res. 2003; 968:69-79.

34. Sprowl JA, Ciarimboli G, Lancaster CS, Giovinazzo H, Gibson AA, Du G, Janke LJ, Cavaletti G, Shields AF, Sparreboom A. Oxaliplatin-induced neurotoxicity is dependent on the organic cation transporter OCT2. Proc Natl Acad Sci USA. 2013; 110:11199-204.

35. De Gramont A, Figer A, Seymour M, Homerin M, Hmissi A, Cassidy J, Boni C, Cortes-Funes H, Cervantes A, Freyer G, Papamichael D, LeBail N, Louvet C, et al. Leucovorinand fluorouracil with or without oxaliplatin as first-line treatment in advanced colorectal cancer. J Clin Oncol. 2000; 18:2938-47.

36. Souglakos J, Mavroudis D, Kakolyris S, Kourousis CH, Vardakis N, Androulakis N, Agelaki S, Kalbakis K, Tsetis D, Athanasiadis N, Samonis G, Georgoulias V. Triplet combination with irinotecan plus oxaliplatin plus continuous-infusion fluorouracil and leucovorin as firstline treatment in metastatic colorectal cancer: a multicenter phase II trial. J Clin Oncol. 2002; 20:2651-57.

37. Di Cesare Mannelli L, Zanardelli M, Failli P, Ghelardini C. Oxaliplatin-induced oxidative stress in nervous systemderived cellular models: Could it correlate with in vivo neuropathy? Free Radic Biol Med. 2013; 61:143-50.

38. Branca JJV, Morucci G, Maresca M, Tenci B, Cascella R, Paternostro F, Ghelardini C, Gulisano M, Di Cesare Mannelli L, Pacini A. Selenium and zinc: two key players against cadmium-induced neuronal toxicity. Toxicol In Vitro. 2018; 48:159-69.

39. Rutkowski DT, Kaufman RJ. A trip to the ER: coping with stress. Trends Cell Biol. 2004; 14:20-8.

40. Rosenberg GA. Neurological diseases in relation to the blood-brain barrier. J Cereb Blood Flow Metab. 2012; 32:1139-51.

41. DosSantos MF, Holanda-Afonso RC, Lima RL, DaSilva AF, Moura-Neto V. The role of the blood-brain barrier in 
the development and treatment of migraine and other pain disorders. Front Cell Neurosci. 2014; 8:302.

42. Lim TK, Shi XQ, Martin HC, Huang H, Luheshi G, Rivest $\mathrm{S}$, Zhang J. Blood-nerve barrier dysfunction contributes to the generation of neuropathic pain and allows targeting of injured nerves for pain relief. Pain. 2014; 155:954-67.

43. Beggs S, Liu XJ, Kwan C, Salter MW. Peripheral nerve injury and TRPV1-expressing primary afferent $\mathrm{C}$-fibers cause opening of the blood-brain barrier. Mol Pain. 2010; 6:74.

44. Cecchelli R, Berezowski V, Lundquist S, Culot M, Renftel M, Dehouck MP, Fenart L. Modelling of the blood-brain barrier in drug discovery and development. Nat Rev Drug Discov. 2007; 6:650-61.

45. Vorbrodt AW, Dobrogowska DH. Molecular anatomy of intercellular junctions in brain endothelial and epithelial barriers: electron microscopist's view. Brain Res Brain Res Rev. 2003; 42:221-42.

46. Chiba H, Osanai M, Murata M, Kojima T, Sawada N. Transmembrane proteins of tight junctions. Biochim Biophys Acta. 2008; 1778:588-600.

47. Fauquette W, Amourette C, Dehouck MP, Diserbo M. Radiation-induced blood-brain barrier damages: an in vitro study. Brain Res. 2012; 1433:114-26.

48. Paris L, Tonutti L, Vannini C, Bazzoni G. Structural organization of the tight junctions. Biochim Biophys Acta. 2008; 1778:646-59.

49. Lourenço Cardoso F, Brites D, Brito MA. Looking at the blood-brain barrier: Molecular anatomy and possible investigation approaches. Brain Res Rev. 2010; 64:328-63.

50. Baeten KM, Akassoglou K. Extracellular matrix and matrix receptors in blood-brain barrier formation and stroke. Dev Neurobiol. 2011; 71:1018-39.

51. Gaman AM, Uzoni A, Popa-Wagner A, Andrei A, Petcu EB. The role of oxidative stress in etiopathogenesis of chemotherapy induced cognitive impairment (CICI)"Chemobrain". Aging Dis. 2006; 7:307-17.

52. Waseem M, Sahu U, Salman M, Choudhury A, Kar S, Tabassum H, Parvez S. Melatonin pre-treatment mitigates SHSY-5Y cells against oxaliplatin induced mitochondrial stress and apoptotic cell death. PLoS One. 2017; 12:e0180953.

53. Waseem M, Kaushik P, Tabassum H, Parvez S. Role of mitochondrial mechanism in chemotherapy-induced peripheral neuropathy. Curr Drug Metab. 2018; 19:47-54. https://doi.org/10.2174/1389200219666171207121313.

54. Lum H, Roebuck KA. Oxidant stress and endothelial cell dysfunction. Am J Physiol Cell Physiol. 2001; 280: C719-C741.

55. van Wetering S, van Buul JD, Quik S, Mul FP, Anthony EC, ten Klooster JP, Collard JG, Hordijk PL. Reactive oxygen species mediate Rac-induced loss of cell-cell adhesion in primary human endothelial cells. J Cell Sci. 2002; 115:1837-46.
56. Schreibelt G, Kooij G, Reijerkerk A, van Doorn R, Gringhuis SI, van der Pol S, Weksler BB, Romero IA, Couraud PO, Piontek J, Blasig IE, Dijkstra CD, Ronken $\mathrm{E}$, et al. Reactive oxygen species alter brain endothelial tight junction dynamics via RhoA, PI3 kinase, and PKB signaling. FASEB J. 2007; 21:3666-76.

57. Lehner C, Gehwolf R, Tempfer H, Krizbai I, Hennig B, Bauer HC, Bauer H. Oxidative stress and blood-brain barrier dysfunction under particular consideration of matrix metalloproteinases. Antioxid Redox Signal. 2011; 15:1305-23.

58. Tabas I, Ron D. Integrating the mechanisms of apoptosis induced by endoplasmic reticulum stress. Nature cell biology. 2011; 13:184-90.

59. Zou P, Chen M, Ji J, Chen W, Chen X, Ying S, Zhang J, Zhang Z, Liu Z, Yang S, Liang G. Auranofin induces apoptosis by ROS-mediated ER stress and mitochondrial dysfunction and displayed synergistic lethality with piperlongumine in gastric cancer. Oncotarget. 2015; 6:36505-21. https://doi.org/10.18632/oncotarget.5364.

60. Lee AS. The ER chaperone and signaling regulator GRP78/ $\mathrm{BiP}$ as a monitor of endoplasmic reticulum stress. Methods. 2005; 35:373-81.

61. Kim R, Emi M, Tanabe K, Murakami S. Role of the unfolded protein response in cell death. Apoptosis. 2006; 11:5-13.

62. Yokouchi M, Hiramatsu N, Hayakawa K, Okamura M, Du S, Kasai A, Takano Y, Shitamura A, Shimada T, Yao J, Kitamura M. Involvement of selective reactive oxygen species upstream of proapoptotic branches of unfolded protein response. J Biol Chem. 2008; 283:4252-60.

63. Schroder M, Kaufman RJ. The mammalian unfolded protein response. Annu Rev Biochem. 2005; 74:739-89.

64. Qie X, Wen D, Guo H, Xu G, Liu S, Shen Q, Liu Y, Zhang W, Cong B, Ma C. Endoplasmic reticulum stress mediates methamphetamine-induced blood-brain barrier damage. Front Pharmacol. 2017; 8:639.

65. Wang J, Yang X, Zhang J. Bridges between mitochondrial oxidative stress, ER stress and mTOR signaling in pancreatic $\beta$ cells. Cell Signal. 2016; 28:1099-104.

66. Ott M, Gogvadze V, Orrenius S, Zhivotovsky B. Mitochondria, oxidative stress and cell death. Apoptosis. 2007; 12:913-22.

67. Cao SS, Kaufman RJ. Endoplasmic reticulum stress and oxidative stress in cell fate decision and human disease. Antioxid Redox Signal. 2014; 21:396-413.

68. Tsujii S, Ishisaka M, Shimazawa M, Hashizume T, Hara H. Zonisamide suppresses endoplasmic reticulum stressinduced neuronal cell damage in vitro and in vivo. Eur $\mathrm{J}$ Pharmacol. 2015; 746:301-7.

69. Go BS, Kim J, Yang JH, Choe ES. Psychostimulant-induced endoplasmic reticulum stress and neurodegeneration. Mol Neurobiol. 2016; 54:4041-48. 
70. Rutkowski DT, Hegde RS. Regulation of basal cellular physiology by the homeostatic unfolded protein response. $\mathrm{J}$ Cell Biol. 2010; 189:783-94.

71. Vercammen D, Beyaert R, Denecker G, Goossens V, Van Loo G, Declercq W, Grooten J, Fiers W, Vandenabeele P. Inhibition of caspases increases the sensitivity of L929 cells to necrosis mediated by tumor necrosis factor. J Exp Med. 1998; 187:1477-85.

72. Fiers W, Beyaert R, Declercq W, Vandenabeele P. More than one way to die: apoptosis, necrosis and reactive oxygen damage. Oncogene. 1999; 18:7719-30.

73. Cauwels JB, Waeytens A, Cuvelier C, Brouckaert P. Caspase inhibition causes hyperacute tumor necrosis factorinduced shock via oxidative stress and phospholipase A2. Nature Immunol. 2003; 4:387-93.

74. McLaughlin B, Hartnett KA, Erhardt JA, Legos JJ, White RF, Barone FC, Aizenman E. Caspase 3 activation is essential for neuroprotection in preconditioning. Proc Natl Acad Sci USA. 2003; 100:715-20.

75. Sandilos JK, Chiu YH, Chekeni FB, Armstrong AJ, Walk SF, Ravichandran KS, Bayliss DA. Pannexin 1, an ATP release channel, is activated by caspase cleavage of its poreassociated C-terminal autoinhibitory region. J Biol Chem. 2012; 287:11303-11.

76. Elliott MR, Chekeni FB, Trampont PC, Lazarowski ER, Kadl A, Walk SF, Park D, Woodson RI, Ostankovich M, Sharma P, Lysiak JJ, Harden TK, Leitinger N, Ravichandran KS. Nucleotides released by apoptotic cells act as a find-me signal to promote phagocytic clearance. Nature. 2009; 461:282-6.

77. Michaud M, Martins I, Sukkurwala AQ, Adjemian S, Ma Y, Pellegatti P, Shen S, Kepp O, Scoazec M, Mignot G,
Rello-Varona S, Tailler M, Menger L, et al. Autophagydependent anticancer immune responses induced by chemotherapeutic agents in mice. Science. 2011; 334:1573-77.

78. Yang F, Zhao K, Zhang X, Zhang J, Xu B. ATP induces disruption of tight junction proteins via il-1 beta-dependent MMP-9 activation of human blood-brain barrier in vitro. Neural Plast. 2016; 2016:8928530.

79. Boyd-Tressler A, Penuela S, Laird DW, Dubyak GR. Chemotherapeutic Drugs Induce ATP Release via Caspase-gated Pannexin-1 Channels and a Caspase/ Pannexin-1-independent Mechanism. J Biol Chem. 2014; 289:27246-63.

80. De Bock M, Culot M, Wanga N, daCosta A, Decrocka E, Bola M, Bultynckc G, Cecchelli R, Leybaerta L. Low extracellular $\mathrm{Ca} 2+$ conditions induce an increase in brain endothelial permeability that involves intercellular $\mathrm{Ca} 2+$ waves. Brain Res. 2012; 1487:78-87.

81. Kaneko Y, Tachikawa M, Akaogi R, Fujimoto K, Ishibashi M, Uchida Y, Couraud PO, Ohtsuki S, Hosoya K, Terasaki T. Contribution of pannexin 1 and connexin 43 hemichannels to extracellular calcium-dependent transport dynamics in human blood-brain barrier endothelial cells. J Pharmacol Exp Ther. 2015; 353:192-200.

82. Pelegrin P, Surprenant A. Pannexin-1 mediates large pore formation and interleukin-1beta release by the ATP-gated P2X(7) receptor. EMBO J. 2006; 25:5071-82.

83. Wang J, Ma M, Locovei S, Keane RW, Dahl G. Modulation of membrane channel currents by gap junction protein mimetic peptides: size matters. Am J Physiol Cell Physiol. 2007; 293:C1112-9. 